\title{
From Global Order to Global Transition
}

Russia and the Future of International Relations

\author{
Andrei P. Tsygankov
}

\section{Abstract}

The world entered the era of change no later than the second half of the 2000s; however, analysts still lack a common understanding of the conditions that surrounded the disintegration of the former world order as well as of the processes, horizons and results of the transition to a new global order. This article discusses what exactly is in store for Russia and when-a growing global disorder caused by the collapse of international institutions created after World War II, the preservation of American domination, or something else? It was the United States that started revising the world order; therefore, Russia's behavior can be considered revisionist only in relation to Washington's revisionist strategy imposed on it. The current post-Washington world transition is analyzed here in the context of theoretical studies concerning the previous post-Vienna, post-Paris, post-Versailles and post-Yalta transitions and their historical experience. The article concludes that the current post-Washington transition is irreversible, yet it may take more time than the previous ones and

\section{Andrei P. Tsygankov}

San Francisco State University, San Francisco, USA.

Professor, International Relations and Political Science

Google Scholar

Scopus AuthorID 7102020604

Tel.: + 7 415-338-7493

E-mail: andrei@sfsu.edu

Address: 1600 Holloway Avenue. San Francisco. CA 94132 Office: HSS 354

The paper partly draws on Tsygankov, 2019, forthcoming.

DOI: $10.31278 / 1810-6374-2019-17-1-52-70$ 
extend beyond 2050. Each country will have to rethink its place and strategy of struggle for survival and development in the new transitional world. Russia is still working to define its strategy, and the success will depend on a combination of asymmetric resistance aimed at upholding the country's vital interests in the world, active efforts to build a new world order, and domestic reforms required for that.

Keywords: world order, world transition, status quo, revisionism, Washington world order, post-Washington transition, Russia

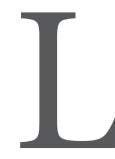

arge-scale global changes are actively discussed by politicians, journalists and experts. However, in modern literature there is still no common understanding on the conditions that surrounded the disintegration of the former world order as well as of the processes, horizons and the results of the transition to a new global order. What has been said and written about past epochs and times is valuable (See, for example, Taylor, 1954; Wolfers, 1965; Morgenthau, 1978; Holsti, 1991; Kissinger, 1994; Cox, Dunne, and Booth, 2001) but is not fully applicable to the present time. What conditions would cause a collapse of the global world order? Has the transition to a different type of world order begun? What are the dynamics and time horizons of this transition? What should be expected as a possible alternative? Part of the problem is that research literature on the crisis of the present world order can hardly be described as extensive. Individual articles and books published so far on the present world order (See, for example, Ikenberry, 2014; Ikenberry, Parmar, and Stokes, 2018; Kissinger, 2014; Mazarr and Rhoades, 2018; Stuenkel, 2016; Bremmer, 2018; Lind and Wohlforth, 2019) are only the beginning of a profound and serious discussion. The studies on Russia and the contemporary global transition are still more limited (see, for example, Radin and Reach, 2017; Sakwa, 2017; Karaganov and Suslov, 2018). These publications are a far cry from the multitude of studies conducted over the last three decades by the so-called transitologists who examined internal political transitions to liberal democracies. Perhaps now, 
when there are problems with democracy in Western countries, too, and when transitology is often called "inverted scientific communism," it is time to analyze global transitions.

Researchers need to clarify the nature of the contemporary world and its development vector. What exactly is in store for us and when-a growing global disorder caused by the collapse of international institutions created after World War II, a new cold or even hot war; a gradual stabilization in a bipolar or multipolar world; the preservation of American domination, albeit in a modified way; or something else?

This article is an attempt to get closer to understanding the problems of global transition with reference to Russia. The main premise of the article is that the world began to change in the mid-2000s and no later than 2008 when Russia intervened in the armed conflict in Georgia. Russia's actions contributed to a relative decline of U.S. power that began soon after its military intervention in Iraq in 2003. Responding to NATO expansion, the Kremlin moved from rhetorical opposition to the U.S.-centered world order to practical actions by ending the U.S. monopoly on the use of force in international affairs, first in Georgia and later in Syria. Although scholars disagree on timing, causes, and implications of American decline for international order (Lieber, 2016; Ikenberry, Parmar, and Stokes, 2018), many share the view that the U.S. has retreated from the status of superpower capable of unilaterally setting and enforcing global rules.

It was the United States that started revising the world order; therefore, Russia's behavior can be considered revisionist only in relation to Washington's revisionist strategy imposed on it. The current post-Washington world transition is analyzed here in the context of theoretical studies concerning the previous post-Vienna, postParis, post-Versailles and post-Yalta transitions, and their historical experience. Another conclusion, related to the main premise, is that the post-Washington transition is irreversible; yet it may take more time than the previous ones and extend beyond 2050. In the conditions of the new transition, each country will have to rethink its strategy of struggle for survival and development. China, India and other rising powers will have to be more active in constructing an 
alternative economic, political, and military order beyond the reach of U.S. hegemonic influence. The post-Western and U.S.-centered world orders will have to learn to coexist to avoid mutually dangerous clashes, while competing for new opportunities on the global scale. Russia's search for self-identity is also far from over, and its success will depend on a combination of asymmetric resistance aimed at upholding the country's vital interests in the world, active efforts to build a new world order, and domestic reforms required for that.

\section{CONDITIONS AND HORIZONS OF GLOBAL TRANSITION}

According to Henry Kissinger's definition, any world order implies a balance of power among major international actors and their recognition of certain rules of conduct (Kissinger, 2014, p. 9). These rules reflect the participating states' ideas about the principles of justice and the distribution of power capabilities. In the theory of international relations, the understanding of transition processes in world politics, taking into account ideas and power capabilities, is characteristic of both realism and constructivism. Realists give top priority to the balance of power, while constructivists assign priority to perceptions and beliefs of international actors. Apparently, both dimensions must be taken into account when one wants to understand the fundamentals of the international system and its changes.

A transition to a new world order, or global transition, begins with challenges to the world order posed by powers that seek to revise it. A transition ensues when such challenges are serious enough to make it impossible for the powers responsible for keeping the world order to maintain it with available means. Meanwhile, the perceptions of world transition on the part of both the powers that wish to keep the status quo and those seeking to revise it do not match their capabilities. The inertially thinking status quo powers are confident that the present difficulties are temporary and that they are able to "uphold the world," whereas the ambitious revisionists tend to exaggerate their ability to change the world. Russia's then Foreign Minister Yevgeny Primakov spoke about these opportunities back in the 1990s, long before the global transition processes began (Primakov, 1996). In America, many 
people viewed, and still view, Russia as an internally weak and purely regional power, although it has already demonstrated its considerable military and political capabilities not only in Eurasia but also in the Middle East (for a detailed analysis see Gunitsky and Tsygankov, 2018).

A transition gains momentum if it is accompanied not only by destructive but also creative processes and efforts to build the foundation of a future world order. In the history of international relations, creative processes of this kind occurred rarely enough to make a smooth transition and were accompanied by wars. In his classic study, War and Change in World Politics, Robert Gilpin showed that powers that considered themselves guarantors of the world order needed wars to prevent the rise of new powers (Gilpin, 1981). It was wars that historically secured a new balance of power and rules of conduct for nations, including defeated countries. The main issue with regard to the latter was whether they should be included as fullfledged actors of the new world order or denied the ability to pursue independent foreign and home policies. Both things are fundamental for great powers, confirming the important spheres of influence and internal sovereignty.

A global transition continues until the processes of destruction, creation and violence, inherent in it, end with the formation of a new balance of power and new rules of conduct, recognized and supported by powers responsible for their implementation.

Since the Westphalian era, the history of international relations has seen several world transitions, which are analyzed in research literature (See, for example: Holsti, 1991; Kissinger, 1994; Schroeder, 1994; Bogaturov, 2000, 2003, 2004; Tsygankov, 2012).

The post-Vienna transition began in the mid-1840s with the weakening of the principles established by the Vienna system, as its members sought to take advantage of the Ottoman Empire's breakup. Russia did not seek to change the rules of the system, wishing only to further protect the rights of Orthodox believers on the territory of the Ottoman Empire, preserve its prestige of a European state and keep its fleet in the Black Sea. England, which had never fully accepted Russia's leadership in the Vienna concert, became the main revisionist 
power. Politicians like Lord Palmerston already in the 1830s thought of increasing England's influence by weakening Russia and Turkey. The economic and political influence of Britain in the Middle East grew, whetting the appetite of the ruling class. France and Austria did not directly challenge the system but wanted more influence for themselves and the weakening of Russia. France wanted new relations with Constantinople, while Austria wanted greater influence over Danube principalities in the Balkans. The Crimean War resolved the growing differences among the powers, as the 1856 Congress of Paris created a new world order. As British historian Alan Taylor wrote, the main target of the war was not Turkey or the Balkans but a revision of the entire European system of power relations (Taylor, 1954, p. 61). Russia, which lost the war, was denied the right to protect Orthodox believers beyond its borders and the right to have a Black Sea fleet.

The post-Paris transition was launched by Alexander Gorchakov's famous note to European powers in 1871, which notified them of Russia's unilateral denunciation of the Congress of Paris provisions. The note referred to both Russia's sovereign rights and violations of the Congress provisions by European powers. Of these, only Britain showed readiness to fight for the status quo. Others were either too weak or, like Prussia which became Germany, made a deal with Russia in exchange for major dividends. The subsequent years, until World War I, are known as the years of anarchy, during which Germany manifested itself as a major revisionist power, while countries of the Triple Entente sought to maintain their positions and influence in Europe by containing Germany. Balkan wars for influence eventually led to a destructive war and the emergence of a new world order based on the Versailles peace treaty of 1918.

The post-Versailles transition was made possible by the rise of Germany and the election of Hitler in 1933 as the country's chancellor. Shortly after that, Germany withdrew from the League of Nations, which it had been forced to enter earlier, resumed military conscription and launched a large-scale military build-up program. In 1936, it reoccupied the Rhineland in violation of the Treaty of Versailles. Attempts by the Soviet Union to create a collective security system 
to contain the aggressor failed due to differences among European powers. In 1938, Hitler concluded agreements with Britain and France in Munich, and in 1939 he signed an agreement with Moscow. Neither agreement prevented a new world war. After the war was over, the allied powers, following difficult negotiations at the Yalta Conference, formulated the contours of a new world order, denying Germany not only spheres of influence but also internal sovereignty.

The Yalta system was soon challenged by the Cold War. There emerged two competing world orders based on antagonistic ideologies and political systems. Both the Soviet Union and the West sought to change the balance of military and political power. They did not recognize each other's spheres of influence and sought to undermine each other's political systems. A series of crises from Berlin to Cuba, Europe and Afghanistan shook the world until the 1980s. Nevertheless, some principles of the Yalta agreements remained valid. In particular, both the Soviet Union and the United States informally recognized their spheres of influence in Europe and viewed the United Nations as a place for debating the principles of international security. This factor facilitated a dialogue between the two major powers and periods of détente. Unlike previous world transitions, the Cold War did not lead to a hot war-largely, due to a nuclear deterrence system. The development of world transition processes during that period could be explained by the Soviet Union's economic slowdown in the 1970s and its growing inability to maintain military parity with the U.S.

As seen from the above, the time spans of international transitions range from relatively short to long. The post-Vienna and postVersailles transitions were short, each taking about ten years and ending in wars among major powers. The post-Paris transition was the longest, taking about forty years. The post-Yalta transition, with the above reservations, lasted from the mid-1970s until 1989 when the Cold War ended. It was followed by the emergence of a new status quo, along with new powers-the U.S. and Western Europe-that were ready to guarantee the observance of the new world order. Since America played the main role in its establishment, it can rightly be called the Washington order. 


\section{RUSSIA AND THE CURRENT GLOBAL TRANSITION}

Russia's position in the Washington world order differed from that of Germany in the Versailles and Yalta systems. No one imposed, or could impose, reparations or disarmament on Moscow, much less a division of the country. Even a discussion of this was impossible. Russia was not defeated in the Cold War; it ended it together with the West on the basis of a temporary unity of interests.

However, the Yalta rules, which Moscow expected to be respected, were in many respects violated by Washington, which was the main revisionist of these rules. Many officials in the Bill Clinton administration viewed Russia as a defeated power and expected it to submit to America's foreign policy priorities (Cohen, 2009; Stent 2014). Few people in the United States believed that the end of the Cold War was a victory for both sides. Washington, as the only superpower, placed emphasis not on reaching new agreements on the delimitation of spheres of responsibility and common rules of conduct, but on global propagation of the principle of democracy, which the American establishment largely viewed as the only acceptable principle of legitimacy (Plattner, 1988).

Russia was treated not like France in the Concert of Europe but much like Imperial Russia defeated in the Crimean War and deprived of a large part of its spheres of influence and internal sovereignty. After the Soviet Union's breakup, the West extended its influence to Eastern Europe, the Balkans, and many of former Soviet republics and contributed to Russia's internal reforms following the Washington consensus model. Because Russia and Western powers jointly negotiated spheres of influences in Yalta following World War II, many in Russia saw the U.S. decision to expand NATO as an attempt to take advantage of Russia's weakness and fill the security vacuum in Europe following the Cold War. Washington did not want to affront the Kremlin and introduced new global rules on an ad hoc basis and without any formal settlement at a special official gathering. Still, the fact that the Warsaw Pact was disbanded, while NATO persisted, meant for America that the West had won the Cold War. 
As a "defeated" power, Russia was expected not to challenge the West's priority, accept American military interventions, and the Western liberal narrative of "universal" values. American and European leaders frequently criticized Russian leaders for violation of human rights and "heavy handed" domestic policies (Chechnya). Such an approach even amounted to attempts to limit Russia's sovereignty in settling internal issues, for instance, in organizing domestic institutions as Russia's leaders saw appropriate.

Not surprisingly, Russia became the main revisionist power in relation to the Washington world order imposed on it (Sakwa, 2017; Bordachev, 2018; Krickovic, 2018). Scholars have established that recognition of a power by the established great powers reduces its assertiveness and revisionism, whereas misrecognition encourages revisionist behavior (see, for example, Tsygankov, 2012; Murrey, 2019)

The analysis of the current post-Washington world transition has revealed several different positions. The most noticeable of them are alarmism and stability positions. Alarmists rightly draw attention to accelerating global trends towards the destruction and decay of various international institutions and subsystems. For example, the authors of the October 2018 Valdai Report used the metaphor of a "crumbling world order" to describe these trends. They believe this process is irreversible and that it is impossible to recreate the foundations of global regulation (Valdai Report, 2018). Another position that is close to that of Alarmists is that a new Cold War is unfolding between Russia and the West, which may have unpredictable consequences. The danger of this confrontation was emphasized, in particular, by Sergei Karaganov and Dmitry Suslov, who see an attempt by the West to change the global balance of power in its favor behind this confrontation (Karaganov, 2016; Karaganov and Suslov, 2018). In the United States, ideas close to alarmism were expressed, in particular, by Stephen Cohen (Cohen, 2009) and Robert Legvold (Legvold, 2016).

Supporters of the stability position, or Stabilizers hold that the idea of a decaying world order is exaggerated. Liberal supporters of this position both in Russia and Western countries consider it possible and desirable to preserve the world order shaped after the 
end of the Cold War. According to Richard Haass, president of the U.S. Council on Foreign Relations, this world order rested mainly on a harmony of interests and led to unprecedented stability and prosperity in the world. People sharing this view, among them Gilford John Ikenberry, a renowned theorist of international relations, admit that the liberal world order is in a deep crisis (Ikenberry, Parmar, and Stokes, 2018), but they attribute this crisis to the way this world order is implemented, rather than to its basic principles. The director of the Russian International Affairs Council, Andrei Kortunov, in his article The Inevitable, Weird World, also insists that there are no alternatives to the world order based on the principles of rationality, normativity and openness (Kortunov, 2016). Russian liberals agree that the international positions of the United States and the West have weakened significantly; yet they may strengthen in the near future as the West remains the leader of political, technological and economic development, while the world order, shaped after the Cold War, is generally rational and needs to be improved rather than transformed. Even if the U.S. falls short of expectations, Russia should pin its hopes on Europe as it positions itself as an integral part of it (Kortunov, 2016; RCIA, 2017; Yavlinsky, 2017).

Some scholars and experts close to realist thinking also consider fears of a world order collapse exaggerated. Realists believe that the world remains, and will largely remain, under the influence of the United States as the sole superpower. It is obvious to them that the U.S. will remain the world's undisputed leader in the development of technology and weapon systems, even despite a relative decrease in America's share in the world economy and trade. For example, Nuno Monteiro, a prominent theorist of unipolarity, links the preservation and development of unipolarity not so much to economic resources and economic shifts in the world, as to the United States' targeted state policy in the field of military technology and military capabilities (Monteiro, 2014, p. 48). A similar view was expressed by William Wohlforth at the latest meeting of the Valdai Club in Sochi. He drew the audience's attention to a persisting gap between the military capabilities of America and the rest of the world (Wohlforth, 2018). 
Both Alarmists and Stabilizers correctly grasp the meaning of the important trends, but they exaggerate their significance. Alarmists underestimate the importance of both destructive and constructive processes in the world, which implicitly lay the ground for a future world order. In addition, they tend to diminish the United States' ability to regenerate the foundations of its power, even though not based on liberal principles, thus sabotaging and prolonging the transition to a new world order. Stabilizers are overly skeptic about the non-West's ability to reduce the aforementioned technological gap and create alternative and stable political and international institutions.

The ongoing world transition has both destructive and creative tendencies, which are closely intertwined. The transition began in the mid-2000s and has since been gaining momentum after a series of color revolutions in Eurasia and the Middle East, irreparable mistakes of the "liberal" West, and the rise of nationalist political parties and sentiments in the world. Although the U.S. remains a military superpower, we are witnessing a shift in military and economic power and a serious weakening of the ideological and political authority of America and the West in the world.

Obviously, the United States can no longer maintain or impose on other countries the rules of the world order created after the end of the Cold War. Until the mid-2000s, this world order rested on America's overwhelming military superiority and its ability to deny other powers the right to conduct independent foreign and domestic policies. Today, Russia, China, Iran, Turkey and other countries are no longer oriented towards the U.S. political model and pursue increasingly active policies to protect their spheres of international influence. New institutional associations and negotiation platforms for regional settlement are now actively created without Washington's participation. Formerly reliable allies and partners of the United States in Asia, the Middle East and Eurasia now position themselves as independent actors and establish independent relations with countries viewed by the U.S. as a threat to peace and national security. At the same time, many U.S. allies are guided today by regional 
realities and do not rely on U.S. readiness to protect their security against possible threats from Russia, China or Iran.

Needless to say, the U.S. still has immense military, economic, information and technological capabilities. For this reason, as well as due to the factor of nuclear danger and other considerations, Russia, China and other countries do not view a full-scale war as a way to complete the global transition. The U.S. and the West will be increasingly compelled or forced to revise the Washington world order as new international rules are gradually established.

This process will be complicated and somewhat slowed down by the aforesaid inadequacy in the parties' perception of the ongoing processes, which is typical of global transitions. Many people in Russia, China and some other countries think that a new world is about to come because the U.S. is already in relative "decline," while Europe has ceased to be a "sovereign international player." These sentiments can lead to wait-and-see attitudes and prevent the establishment of alternative international institutions and the implementation of essential domestic reforms. Europe and America, on their part, continue to rely on the power of technology, sanctions and other economic instruments in their attempts to make Russia, Iran and other countries comply with global rules of conduct, which are important for the West.

Meanwhile, the demonstration by critics of the West of their asymmetrical capabilities and ensuing crises lead to the gradual development of new spheres of influence and economic growth beyond U.S. control. New rules of international conduct will emerge, which will compete with Western ones and which will require universalization and global recognition. This process will be long. Obviously, the post-Washington transition will take more time than the previous ones, including the post-Paris transition, and may extend beyond 2050. Such a duration is dictated, firstly, by the impossibility of a major war fraught with mutual nuclear annihilation, and secondly, by the continuing asymmetry of the world, in which it is much more difficult to compete with the United States than in conditions of real multipolarity. 


\section{FUTURE STRATEGIES OF RUSSIA AND OTHER POWERS}

In the era of half-life and world transition, only those survive who can adapt external and internal conditions to their needs, thus exerting an important influence on the balance of power and rules in a future world order. A withdrawal into isolation, even temporary, is not possible today due to the "turbulence" of the global world and its relative openness. The present time requires strategies in which firmness in defending sovereignty would be combined with a flexible ability to create something new and desirable in the economic, information, military, and political spheres. The implementation of such strategies will require a strong, creatively minded and target-focused state. Such a state should be able to go beyond economic macro-regulation, invest in optimal international projects and support sectors and industries that are the most promising for that purpose (Hemerijck, 2013; Tsygankov, 2015; Kurlantzick, 2016).

European countries interested in preserving the former "liberal" world order will have to broaden their horizons of thinking and change internally, since the "European Union" project is no longer a guarantor of internal prosperity, nor a model for others to follow. It is hard to tell how this project should be overhauled, but its success in the future world order after 2050 is far from guaranteed. Obviously, the EU will have to turn towards Asia and Eurasia, but European elites have yet to realize the importance of such a turn and prepare for it.

This also partly applies to the United States, but only if Donald Trump turns out to be an aberration and if the new Democratic elite demonstrates willingness for global economic and political integration. More likely is the continuation, in one way or another, of the Trumplaunched great-power nationalism project, already supported by a large part of the U.S. public and elites. The project is aimed at reducing Washington's international obligations and retaining its superpower status, especially in the military-industrial, energy and IT spheres (Posen, 2018). To achieve this goal, America will need internal transformations and a new foreign policy that will not be limited to measures of military-political pressure and economic sanctions, which are hallmarks of Trump's policy. Such measures have already been used 
against North Korea, China, Iran, Europe, Russia, and Latin American countries. Despite Washington's confidence that its policy of diktat will be effective, these measures may cost it dearly in the future.

The strategy of revisionist powers should combine measures of asymmetrical resistance to uphold their major interests in the world and active efforts to build a world order that would be alternative to the previous one and carry out domestic reforms required for that. Asymmetry in defending basic national interests today is not only necessary but also quite possible. As Otto von Bismarck once said, there are times when the strong is weak because of his scruples and the weak grows strongbecause of his audacity. Today, weakness is a distinguishing feature of not only countries but also international associations of the once-united West, which opens up new opportunities for Russia, China and all those not willing to return to the position of secondrate powers. The goal of asymmetrical counteraction is achievable as it is not a victory over the adversary but its inability to continue the offensive. As Brantly Womack, a theorist of asymmetric international relations, wrote about such relations, the weaker side cannot threaten the position of the stronger side, but the stronger side cannot impose its will on the weaker side at an affordable cost (Womack, 2016, p. 1).

The formulation and implementation of such a strategy will involve many difficulties, including the risk of confronting the more developed economies, the choice of internal development areas, the identification of promising international projects, and administrative strengthening of the state. The protection of basic interests should be commensurate with creative goals for a relatively long-term (beyond 2050) perspective.

The ongoing world transition is difficult for those who have not yet taken sides regarding the new world order. The practice of non-aligned countries during the Cold War years shows that playing both sides of the fence is very difficult, yet possible. Partly this is already happening. Countries that used to belong to the U.S. sphere of global influence are now building their own relations with China, Russia and other revisionist powers. For example, they sign defense contracts with them, despite Washington's protests. Yet, today this strategy involves considerable 
difficulties. Its implementation requires not only strong political will, but also a certain balance of power in the world and consent from external powers. Both factors are now lacking. The world is witnessing a global reshaping of markets, regional systems, and military-political alliances, which complicates the choice for many countries.

Each country has to make a difficult choice. The global transition has begun and cannot be reversed. A new world order is on the horizon, and the real struggle for it is still ahead. New issues on the agenda are initiative, will and the ability to make strategic decisions. The alternatives are chaos and a loss of the status of a major player in world politics.

\section{TOWARDS THE FUTURE UNDERSTANDING OF THE GLOBAL TRANSITION}

Researchers of the global transition are yet to answer many important theoretical questions, which were only partly discussed in this article. These are the balance of power and its perception by major international players; the nature and degree of antagonisms between their ideologies and values; the role of domestic politics; and the use of new methods of governance and influence in international rivalry. Answers to these questions should help rethink traditional boundaries in the theory of international relations, which separate realists, liberals and constructivists.

It seems that a major factor in understanding the present and future global transition processes will be a global rethinking of (asymmetric) resources available to international actors, ideas and perceptions of the leaders of major powers and the nature of internal political processes. For example, researchers of power resources and the international political system are to re-evaluate the categories of geopolitics, economic sanctions, propaganda, and cyber technologies. The international confrontation is increasingly shifting to these areas, and states are actively developing new competencies in the struggle for power and influence. Under the conditions of strategic uncertainty, the understanding of world order processes from the position of polarity and structure of the international system, which is typical of structural realism, is not enough and should be complemented with 
the understanding of new capabilities of modern states (Womack, 2016; Fridman, 2018; Musgrave, 2019).

Another important factor is a new understanding of the role played by the leaders of major global and regional powers and their ideas of a better and just world order. The idea that the global competition is between the liberal-minded United States and other Western countries, on the one hand, and non-Western supporters of the Westphalian world order, on the other, became obsolete several years ago. It should be replaced by a more flexible and realistic understanding of complex ideological and political cooperation and rivalry in a world where there can be global alliances of nationalists, liberals, left and right populists and representatives of other political groups, all united into a single coalition of Western and non-Western leaders. A new analysis of beliefs and characters of leaders is also necessary because their interpretation from the position of so-called "rationality" in making decisions and choosing strategies of international behavior has repeatedly proven false. Along with understanding the rational, researchers of global transition should seriously analyze the subjectivity and "voluntarism" of leaders who can spring pleasant and unpleasant surprises.

Finally, it is important, as never before in recent decades, to assess the significance of domestic politics in international political processes. The world is undergoing deep-rooted national and international transformations accompanied by ideological reassessment of the customary understanding of liberalism, nationalism and other "isms" which will have a decisive influence on the character of leaders and their choice of international behavior strategies. The nature and degree of internal political stability of societies and their ability to survive, counter external pressure and mobilize to resolve important strategic issues are of no less fundamental importance.

\section{References}

Bogaturov, A.D. (ed.), 2000. Sistemnaya istoriya mezhdunarodnyh otnoshenī̄ [Systemic history of international relations]. Vol. 1-2. Moscow: Moskovskiī rabochiī. 
Bogaturov, A.D. (ed.), 2003. Sistemnaya istoriya mezhdunarodnyh otnoshenii [Systemic history of international relations]. Vol. 3. Moscow: NOFMO.

Bogaturov, A.D. (ed.), 2004. Sistemnaya istoriya mezhdunarodnyh otnoshenii [Systemic history of international relations]. Vol. 4. Moscow: NOFMO.

Bordachev, T., 2018. Revisionism of powers in the changing historical context. Russia in Global Affairs, 16(3), pp. 46-65. Available at: https://eng. globalaffairs.ru/number/Revisionism-of-Powers-in-the-Changing-HistoricalContext-19802

Bremmer, I., 2018. Us vs. Them: the failure of globalism. New York: Portfolio.

Cohen, S., 2009. Soviet fates and lost alternatives: from Stalinism to the New Cold War. New York: Columbia University Press.

Cox, M., Dunne, T., and Booth, K. (eds.), 2001. Empires, systems, and states: great transformations in international politics. Cambridge: Cambridge University Press.

Fridman, O., 2018. Russian hybrid warfare: resurgence and politicization. New York: Oxford University Press.

Gilpin, R., 1981. War and change in world politics. Cambridge: Cambridge University Press.

Gunitsky, S. and Tsygankov, A., 2018. The Wilsonian bias in the study of Russian foreign policy. Problems of Post-Communism, 65(6), pp. 385-393.

Hemerijck, A., 2013. Changing welfare states. New York: Oxford University Press.

Holsti, K.J., 1991. Peace and war: armed conflicts and international order, 16481989. Cambridge: Cambridge University Press.

Ikenberry, G.J. (ed.), 2014. Power, order, and change in world politics. Cambridge: Cambridge University Press.

Ikenberry, G.J., Parmar, I. and Stokes, D., 2018. Ordering the world? Liberal internationalism in theory and practice. International Affairs, 94(1), pp. 1-5.

Kissinger, H., 1994. Diplomacy. New York: Simon \& Schuster.

Kissinger, H., 2014. World order. New York: Penguin Books.

Karaganov, S., 2016. Russian foreign policy: "We are smarter, stronger and more determined." Interview by Neef, C., Spigel, 13 July [online]. Available at: <http:// www.spiegel.de/international/world/interview-with-putin-foreign-policyadvisor-sergey-karaganov-a-1102629.html> [Accessed 05 January 2019]. 
Karaganov, S. and Suslov, D., 2018. A new world order: A view from Russia. In: Peter W. Schulze (ed.). Multipolarity: the promise of disharmony. Campus Verlag.

Kortunov, A., 2016. The inevitable, weird world. Russian Council of International Affairs, 20 July [online]. Available at: <http://old.russiancouncil.ru/en/ inner/?id_4=7930\#top-content> [Accessed 06 January 2019].

Krickovic, A., 2018. Russia's challenge: a declining power's quest for status. Ponars Policy Memo 543, October.

Kurlantzick, J., 2016. State capitalism: How the return of statism is transforming the world. New York: Oxford University Press.

Lieber, R. J., 2016. Retreat and its consequences: American foreign policy and the problem of world order. Cambridge: Cambridge University Press.

Legvold, R., 2016. Return to Cold War. Cambridge: Polity Press.

Lind, J. and Wohlforth, W.C., 2019. The future of the liberal order is conservative. Foreign Affairs, March-April

Mazarr, M. J. and Rhoades, A. L., 2018. Testing the value of the postwar international order. Washington, DC: RAND.

Monteiro, N., 2014. Theory of unipolar politics. Cambridge: Cambridge University Press.

Morgenthau, H.J., 1978. Politics among nations: the struggle for power and peace. Fifth edition, revised. New York: Alfred A. Knopf.

Murrey, M., 2019. The Struggle for recognition in international relations: status, revisionism, and rising powers. New York: Oxford University Press.

Musgrave, P. 2019. Asymmetry, hierarchy, and the Ecclesiastes trap, International Studies Review [online]. Available at: $<$ https://academic.oup.com/ isr/advancearticle-abstract/doi/10.1093/isr/viz002/5303908? redirectedFrom= PDF> [Accessed 06 January 2019].

Plattner, M.C., 1988. Democracy outwits the pessimists. The Wall Street Journal, 12 October.

Primakov, Ye.M., 1996. Na gorizonte - mnogopolyusnyiii mir [A multipolar world looms at the horizon]. Mezhdunarodnaya zhizn', Vol. 10.

Radin, A. and Reach, C. B., 2017. Russian views of the international order. Washington, DC: RAND. 
RCIA, 2017. Tezisy po vneshneī politike i pozitsionirovaniyu Rossii v mire (20172035 gg.) [Thesis on Russia's Foreign Policy and Self-Presentation in the World (2017-2035)]. Moscow: Russian Council of International Affairs.

Sakwa, R., 2017. Russia against the Rest: the post-Cold War crisis of world order. Cambridge: Cambridge University Press.

Schroeder, P.W., 1994. The transformation of European politics, 1763-1848. Oxford: Oxford University Press.

Stent, A., 2014. The limits of partnership: U.S.-Russian relations in the twentyfirst century. Princeton: Princeton University Press.

Stuenkel, O., 2016. Post-Western world: how emerging powers are remaking global order. Cambridge: Polity Press.

Taylor, A.J.P., 1954. The struggle for mastery in Europe, 1848-1918. Oxford: Oxford University Press.

Tsygankov, A. P., 2012. Russia and the West from Alexander to Putin. Cambridge: Cambridge University Press.

Tsygankov, A., 2015. Sil'noye gosudarstvo: teoriya i praktika v XXI veke [Powerful state: theory and practice in the 21st century]. Valdaiskiye zapiski [pdf]. Available at: <http://ru.valdaiclub.com/files/22160/> [Accessed 04 January 2019].

Tsygankov, A., 2019, forthcoming. Russia and America: the asymmetric rivalry. Cambridge: Polity Press.

Valdai Report, 2018. Living in a crumbling world. October [pdf]. Available at: $<$ http://valdaiclub.com/files/20155/> [Accessed 05 January 2019].

Wohlforth, W., 2018. Presentation at the Valdai International Forum, October 16.

Wolfers, A., 1965. Discord and collaboration: essays on international politics. Washington, DC: Johns Hopkins University Press.

Womack, B., 2016. Asymmetry and international relationships. Cambridge: Cambridge University Press.

Yavlinsky, G., 2017. Rossii ne stoit nadeyatsya na "novuyu Yaltu” [Russia should not hope for a "new Yalta"]. Nezavisimaya gazeta, 26 September [online]. Available at: <http://www.ng.ru/ideas/2017-09-26/5_7081_future.html> [Accessed 05 January 2019]. 